\title{
Centrichnus, new ichnogenus for centrically patterned attachment scars on skeletal substrates
}

\author{
RICHARD G. BROMLEY and JORDI MARTINELL
}

\begin{abstract}
Bromley, R. G. \& Martinell, J.: Centrichnus, new ichnogenus for centrically patterned attachment scars on skeletal substrates. Bull. geol. Soc. Denmark, vol. 38, pp. 243-252, Copenhagen, February 19th, 1991. https://doi.org/10.37570/bgsd-1990-38-21

Two characteristic and common trace fossils, lightly etched into the surfaces of skeletal substrates in marine environments, are named Centrichnus eccentricus igen. et isp. nov., and $C$. concentricus isp. nov. respectively. The first is new, not having been described in recent or fossil material before. It corresponds to the attachment scars produced by anomiid bivalves where they anchor their unique calcified byssus to the substrate. $C$. concentricus, on the other hand, is well known but hitherto has not been named. It corresponds to the etching scars produced beneath verrucid cirripedes on calcareous substrates.
\end{abstract}

R. G. Bromley, Institut for Historisk Geologi og Paloentologi, Øster Voldgade 10, 1350 Copenhagen K, Denmark. J. Martinell, Laboratori de Paleontologia, Facultat de Geologia, Zona Universitaria de Pe-dralbes, 08071 Barcelona, Spain. April 1st, 1990.

\section{Introduction}

Sessile epilithic organisms attach themselves to their substrate in many ways. Permanently cementing species may secrete a carbonate skeleton in intimate contact with the substrate: such groups include serpulid polychaetes, ostreid bivalves and craniacean brachiopods. However, in some such cases the mineral-mineral interface can represent a plane of weakness, allowing the physical detachment of the encruster. (Balanid barnacles are among the exceptions to this.)

Perhaps the most secure attachment for an epilith is an organic anchor. Epibyssate bivalves, like the mytilids for example, use rapidly produced, flexible, proteinaceous byssus threads for anchorage, which have the advantage that they may be abandonned when the animal requires to move elsewhere.

For greatest securiy, were the organism requires a permanent location, an organic contact etched into a carbonate substrate provides the most durable attachment. Examples are the holdfasts of some phaeophycean seaweeds (Barnes \& Topinka 1969) and the pedicles of brachiopods (Bromley \& Surlyk 1973), which etch the substrate and produce tenaceous anchorage. The etching produced by brachiopod pedicles normally creates a characteristic scar, which is readily recognizable in fossil material and has received the ichnogenus Podichnus.
In the present article, two further examples of cementing animals that etch their substrate are described, one new and the other long recognized; these are the anomiid bivalves and the verrucid barnacles respectively (fig. 1). Both produce etching traces that are readily recognizable as trace fossils and are named as such here on the basis of fossil material.

\section{Anomiid bivalves}

\section{Mode of life}

The saddle oysters are characteristic members of epilithic communities on rocky intertidal shores and in shallow water and shelf settings, from the Cretaceous to today. The Anomiidae (superfamily Anomiacea) are unique among bivalves in their mode of attachment, which is known as 'byssal cementation' (Yonge 1977). Lying with the right valve adpressed against the substrate, a greatly enlarged and calcified byssus passes through an embayment in that valve (fig. 2) and fixes the animal securely. As the animal grows, the byssal embayment is enlarged through resorption of shell material to accommodate a steadily growing byssal plug. The animal is thus attached viscerally to the substrate and not by cementation of the skeleton.

Yonge (1977) observed that detachment of an 

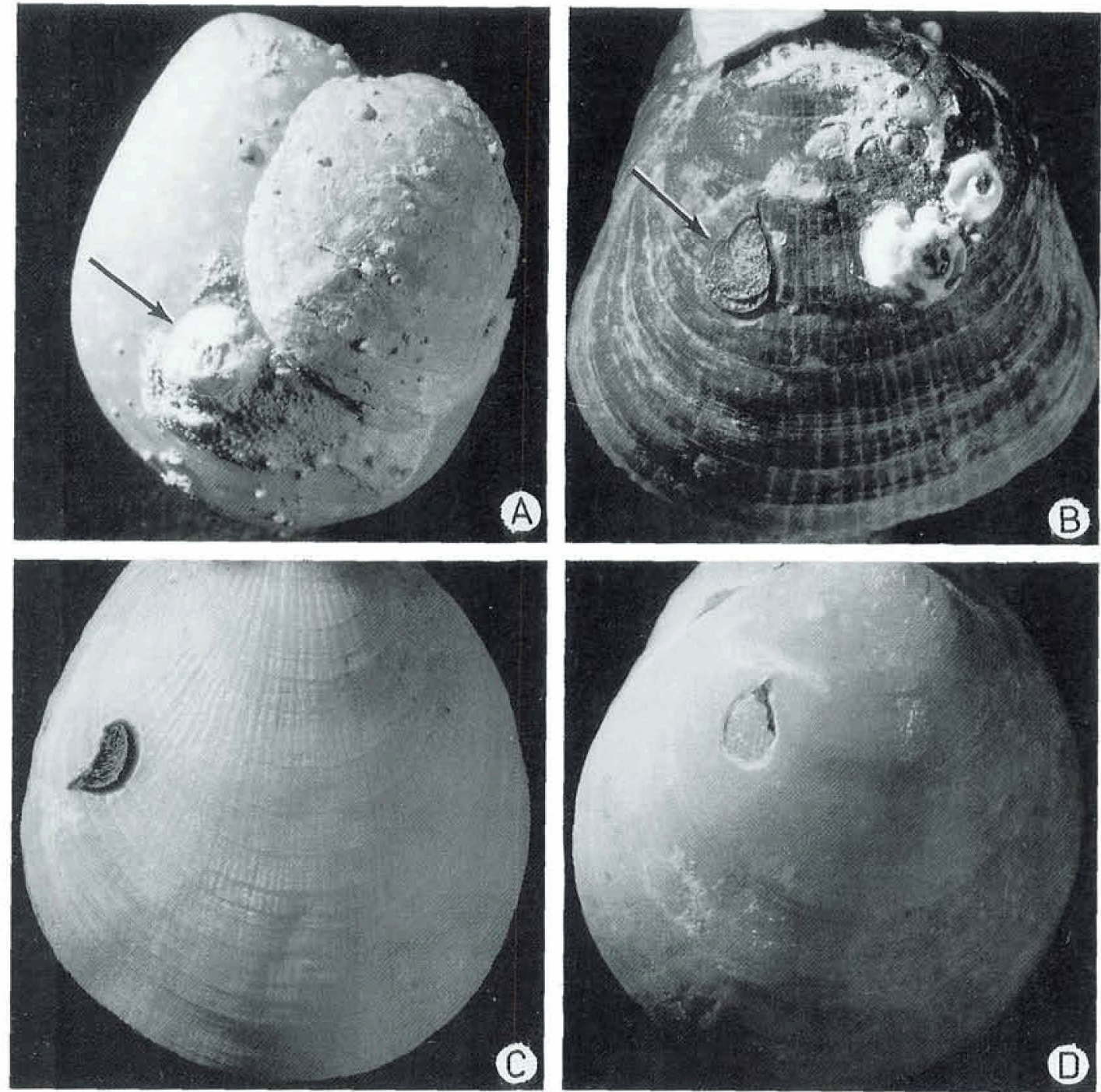

Figure 1. Four recent brachiopods collected alive in Norwegian coastal waters. A: Macandrevia cranitum having on its pedical valve both of the trace-making animals discussed in this article; Anomia ephippium to the right and Verruca stroemia lower left centre. The Anomia shell is $15 \mathrm{~mm}$ high (umbo to ventral margin), the sear (fig. 2) hidden beneath it is $3 \mathrm{~mm}$ long. Mossdalsfjord, -50 to $-100 \mathrm{~m}$. MGUH $19735, \times 3$. B: Hemithiris psittacea bearing a fresh byssal plug from A. ephippium (arrow) on its brachial valve. Despite the well-developed periostracum on the brachiopod, there is a clear etching scar around the plug. Reinøysund, Porsangerfjord, -40 to $-60 \mathrm{~m}$. MGUH 19736, $\times 11$. C. Terebratulina retusa carrying a fresh byssal plug of $A$. ephippium in an etching trace on its brachial valve. Mossdalsfjord, -25 to $-100 \mathrm{~m}$. MGUH $19737, \times 11$. D: M. cranium showing an attachment scar of an A. ephippium on the brachial valve. Mossdalsfjord, -50 to $-100 \mathrm{~m}$. MGUH $19738, \times 11$.

(adult) anomiid from its support is unlikely while reattachment is impossible. However, Jackson (1861) noted that in juveniles the byssus is not calcified, and until it becomes so, the animal may shift its location as do more normal epibyssate bivalves. After byssal calcification, however, attachment is permanent.

The calcified byssus in fresh condition is extremely durable, comprizing mineralized plates or laminae tightly packed into an organic matrix. Pujol et al. (1970) analyzed the calcareous material and found it to consist of aragonite, but also containing traces of calcite. (The calcified plug stains black with Feigl's solution, indicating aragonite). This is in good agreement with the valves, in which the ostracum is of calcite but the myostracum and associated layers are of aragonite (Taylor et al. 1969). 

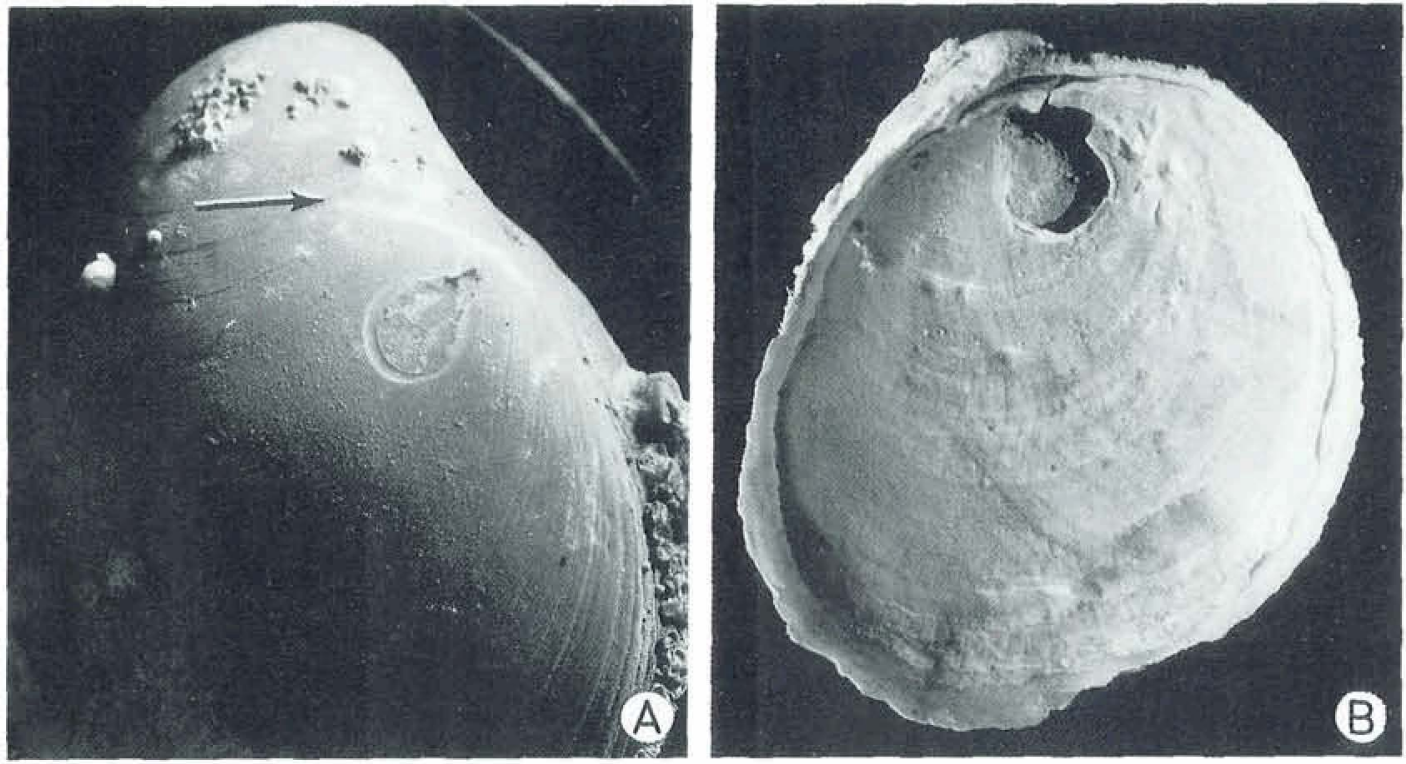

Figure 2. The Anomia ephippium individual shown in fig. 1A, detached from its substrate. The trace-maker is viewed from beneath, showing the byssal embayment in the lower valve. The byssal plug is visible within this, corresponding to the attachment scar it has produced in the substrate (A). Arrow indicates etched line corresponding to the hinge-linc of the anomitd.

Etching the substrate

Despite our detailed knowledge of the anatomy and development of the anomiids, previous investigators have not recorded the fact that the surface of the substrate to which the byssus is attached is first etched (e.g., Jackson 1861; Bucquoy et al. 1898; Sassi 1905; Yonge 1977 and Seed 1980). In juvenile animals the whole byssal plug is sunken into a depression (fig. IB, C, D), whereas in calcified plugs, each growth increment
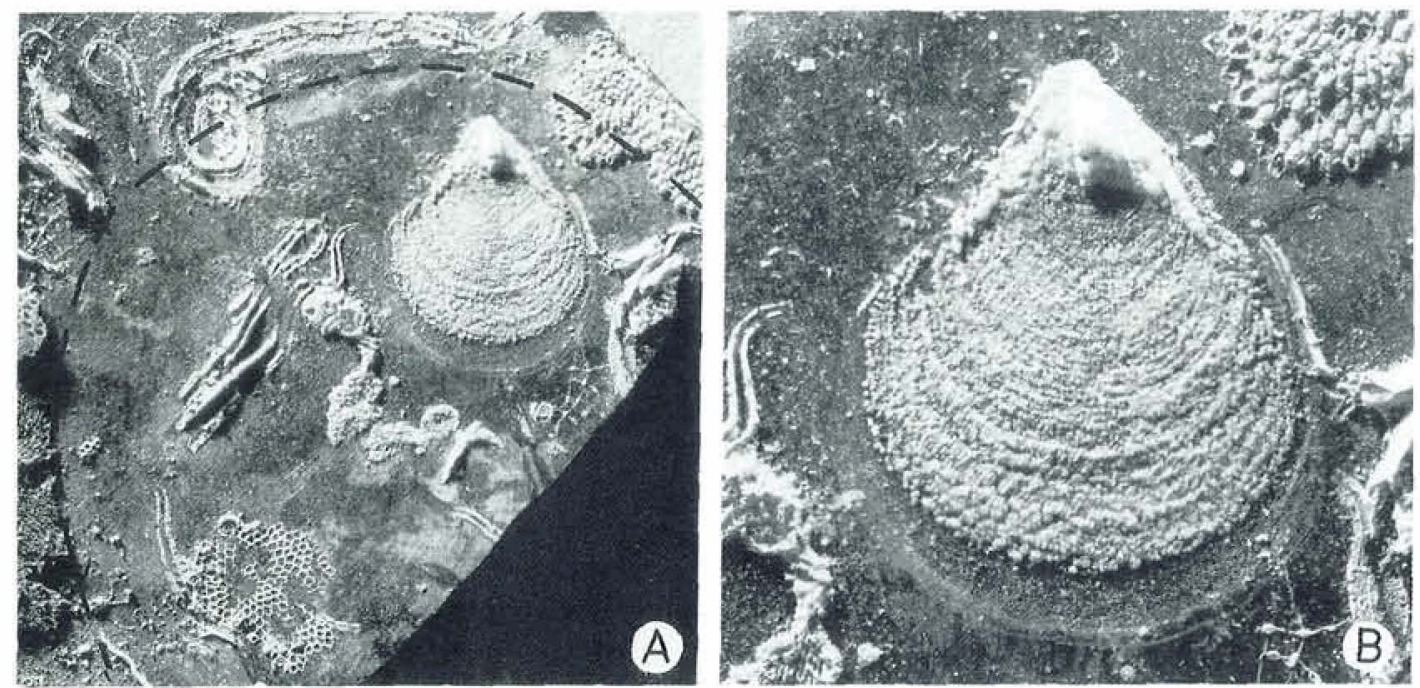

Figure 3. The byssal plug of the anomiid Pododesmus zeylanica on the inner surface of a shell of the pinnid Atrina zelandica. A: The outline of the lower valve of the anomiid is seen (broken line) where it has hindered growth of other epiliths and, at top, slight etching or abrasion of the substrate has occurred along the hinge-line. $\times 2$. B: calcification of the byssal plug increases towards older parts. and the newest growth increment is marked by a concentric etching groove in the substrate. $\times 5$. Doubtful Sound, South Island, New Zealand, $-20 \mathrm{~m}$. MGUH 19739 

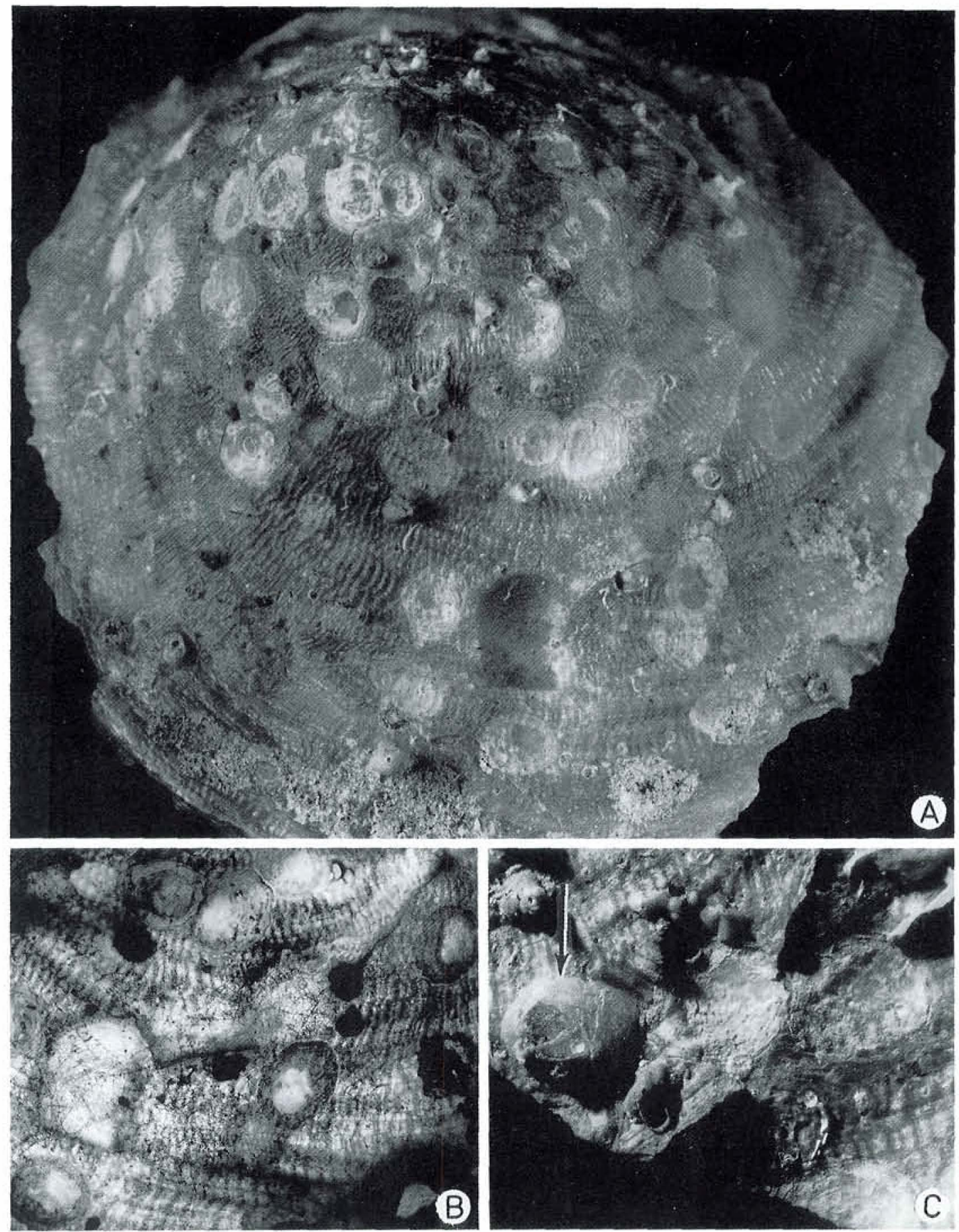

Figure 4. A: Xenophora sp. covered with etching scars produced by verrucid barnacles. The shell was occupied by a hermit crab. Dredged from $-180 \mathrm{~m}$, off Paine's Bay, Barbados. MGUH 19740, × 2.5. B: Part of the same shell viewed in transmitted light; note the thinner shell beneath the central depressions of the verrucid scars. $\times 2.5$. C: Another specimen of the same species and provenance, showing two scars (arrows) and, at left, a verrucid barnacle still attached to its substrate. MGUH $19741, \times 5$. 
produces a corresponding arcuate trough in the substrate (fig. 3 ).

\section{Taphonomy}

On the death of the animal, the shells fall away as the viscera putrify, leaving the byssal plug still firmly attached to the substrate. In the case of juvenile Anomia ephippium, the uncalcified byssus remains attached within its scar for some time after the rest of the animal has fallen off (fig. 1B, C). However, decomposition of the organic material, and the work of scavengers, soon frees the etching trace of all remains of the causative organism (fig. 1D).

This is not so for well calcified byssal plugs of adult anomiids, which remain attached to their substrate more tenaceously. Owing to the predominantly aragonitic composition, however, the plug will be susceptible to early dissolution after burial. Nevertheless, remains of the byssus may still be found in fossil material (figs. $5 \& 6 \mathrm{C}$ ).

The shell of anomiids is very thin and extremely friable, consisting chiefly of foliacious calcite. Preservation potential is negligible except under special conditions of rapid burial. All in all, the attachment scar probably has a higher likelihood of survival than the body fossil.

\section{Verrucid cirripedes}

Among the operculate barnacles, the Verrucidae alone have an uncalcitized basal membrane, placing viscera into direct contact with the substrate. Where this surface is calcareous, a characteristic etching trace is commonly produced in the substrate. As long ago as 1854, Darwin recorded this etching activity beneath Verruca stroemia, and found comparable scars on shells of Tertiary age.

The best description of verrucid scars, both modern and fossil, is that by Radwański (1977). A central, rounded depression is surrounded by a flat shelf that is incised very shallowly into the surface. The margin of the shelf is crenulated in correspondence with the ornament of the plates of the barnacle, and concentric growth-lines may be present on the shelf, each showing the same crenulated outline (fig. 4).

Not all individuals etch their substrate. Pilsbury (1916) searched in vain for their scars in
American material. Radwański (1977) also noted this. In the Miocene Korytnica Basin in Poland, verrucids etched their substrate in littoral and shallow-water settings, but not in deeper locations in the basin.

Similarly, in Miocene offshore sands at Nawodzice, Radwański (1977) reported that verrucids occurred both on oysters and on living red algae. In the case of the oysters, well developed scars were produced; however, none were seen beneath individuals encrusting red algae. The alga had in part embedded the barnacles by growing up around them; the verrucids were thus secure and etching their anchorage became unnecessary.

Other operculate cirripedes, possessing a basal plate, do not appear to modify the substrate they cement themselves to. A Pleistocene example of oval scars having indented outlines was referred to balanid barnacles by Brande (1982), but this may be a mistaken attribution.

\section{The trace fossils}

Because the etched scars produced by anomiids and verrucids are morphologically highly characteristic, and comparable trace fossils are abundant in the geological record, they require to be named as ichnotaxa. The two types of scar have several features in common. Both express the growth of the causative organism in a series of centric rings or arcs. Therefore, we introduce them as two ichnospecies of a single ichnogenus.

\section{Centrichnus igen. nov.}

Diagnosis: shallow biogenic etching traces on carbonate lithic or skeletal substrates comprizing centrically arranged arcuate or ring-shaped grooves.

Type ichnospecies: C. eccentricus igen. et isp. nov.

Centrichnus eccentricus isp. nov.

Diagnosis: tear- or drop-shaped Centrichnus comprizing a series of bundled or crowded, bowshaped grooves concave toward the pointed end. 

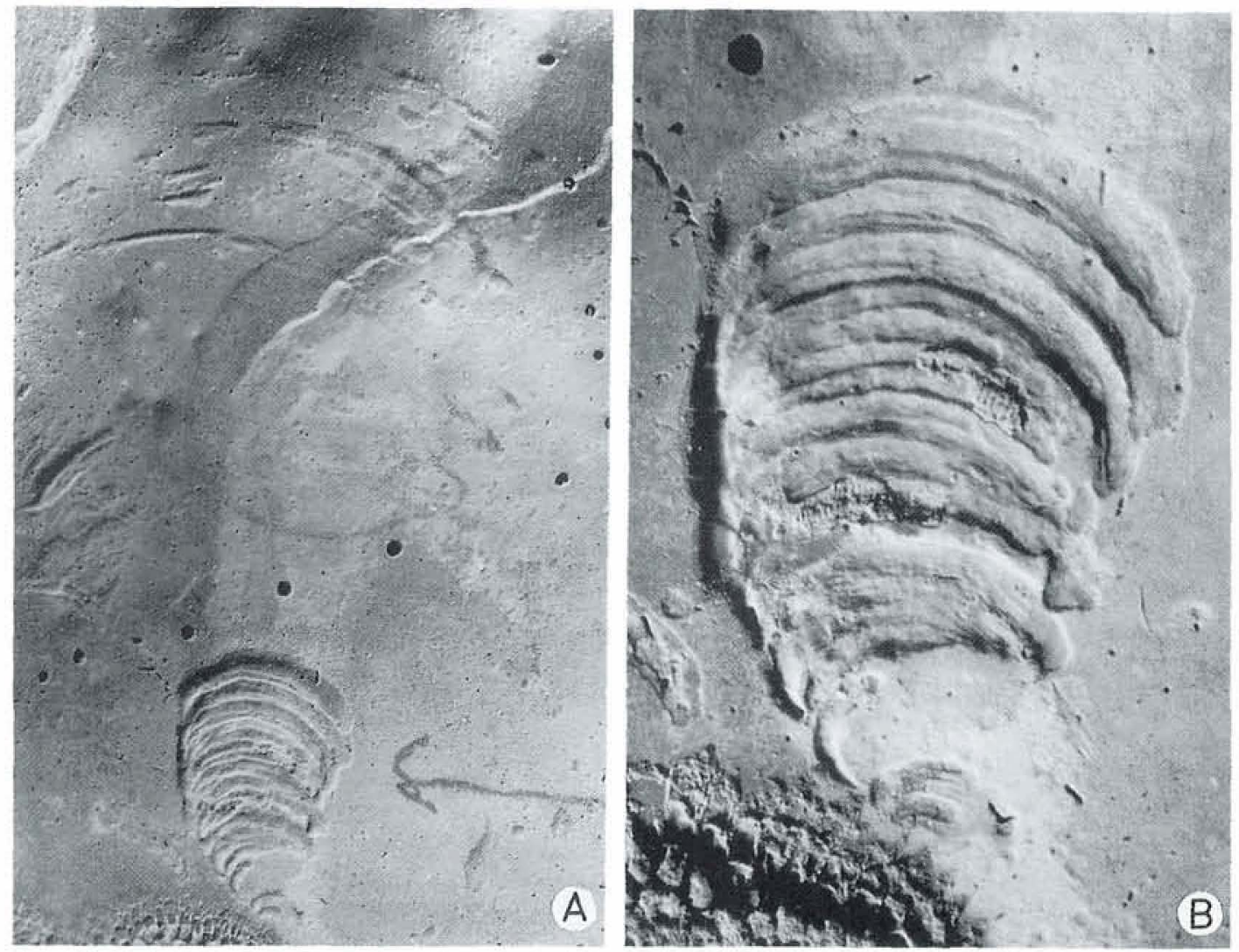

Figure 5. Holotype of Centrichnus eccentricus, nov. A: General view showing, in addition to the compact group of grooves characteristic of the ichnotaxon, a further group of fainter ares and pits. The compact group corresponds to the byssal plug of an anomiid, whereas the distal array are ascribed to successive positions of the growing valve margin. $\times 3$. B: Close view of the compact group of grooves, $\times 8$.

Holotype: a well-developed example on the inner surface of a valve of Arctica islandica (fig. 5). MGUH 19742.

Type locality: Palamós, Girona, Catalonia, Spain: Pleistocene, Würmian IV (12000 B.P.).

Paratypes: MGUH 19743 (fig. 6A), in Ostrea lamellosa from Els Olivets, Vilacolum, Girona, Spain: Pliocene. MGUH 19744 (fig. 6B), in a belemnite, probably from Misburg, near $\mathrm{Ha}$ nover, Germany; Quadratus Zone, L. Campanian, Upper Cretaceous. MGUH 19745 (fig. 6C), on the inner surface of a valve of Arctica islandica from Cap de Creus, Girona, Spain (Pliocene). MGUH 19746 (fig. 6D), on a valve of Glossus humanus from Palamós (Pleistocene, Würmian IV).

Repository: all type material is housed in the
Geological Museum of the University of Copenhagen, Denmark, with MGUH numbers.

Description: the overall outline of the trace fossil is normally compact, of straight or curved teardrop or pear shape; within this outline the surface is patterned with bow-shaped grooves comprizing arcs or parts of ovals, curved about a centre that is at or beyond the narrow end of the trace. Few examples exceed $10 \mathrm{~mm}$ in length (accurate measurement rarely possible as the narrow end commonly is indistinct or lacking); depth of grooves normally less than $0.1 \mathrm{~mm}$.

Weakly developed examples of $C$. eccentricus may resemble the trace fossil Renichnus arcuatus, as introduced by Mayoral (1987). In full development, however, that form is the spiral etching attributable to vermetid gastropods and well illustrated by Radwański (1977, pl. 10a-c). 

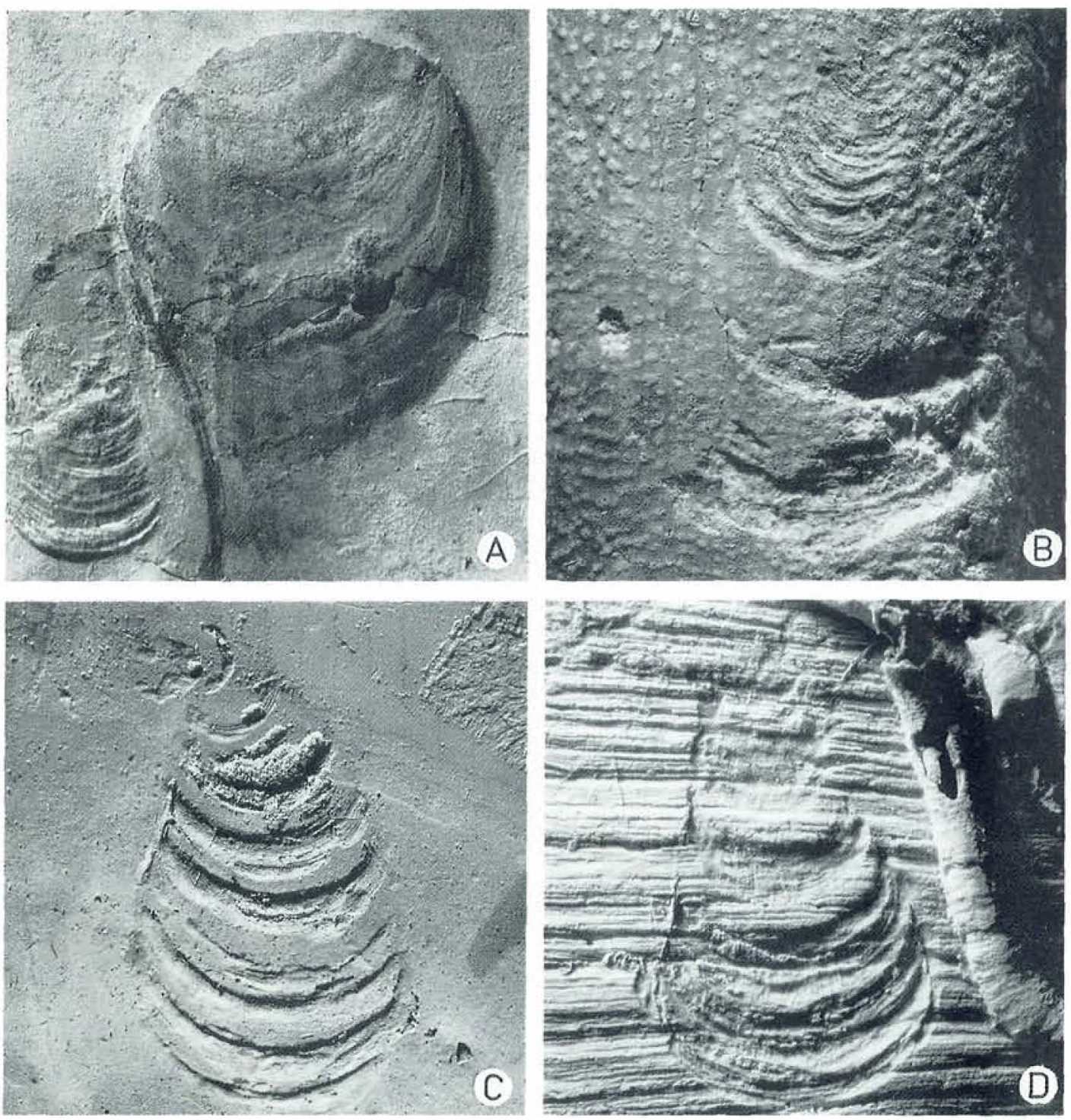

Figure 6. Paratypes of Centrichnus eccentricus. A: MGUH 19743, beside the adductor muscle myostracum of Ostrea edtulis, $\times 3$. B: MGUH 19744. a specimen showing both the compact set of grooves as well as the accessory grooves, ef. fig. 4A. $\times 5$. C: MGUH $19745, \times 5$. D: MGUH 19746, ×6.

Interpretation: owing to the remarkable similarity of examples from the Cretaceous to Recent, it is likely that these characteristic trace fossils are the work of anomiid bivalves. In rare examples (but including the holotype and the Cretaceous paratype) there is, in addition to the compact group of grooves representing $C$. eccentricus, a further, less conspicuous set of grooves and pits (figs, 5A \& 6B); these extra structures correspond well to successive positions of the growing ventral edge of the lower valve of the bivalve.
Range: Upper Cretaceous to Recent.

Centrichnus concentricus isp. nov.

Diagnosis: a central, rounded depression surrounded by a flat shelf lightly etched into the substrate. The shelf has an oval, crenulated perimeter, and may be patterned with concentric rings having the same crenulations. 

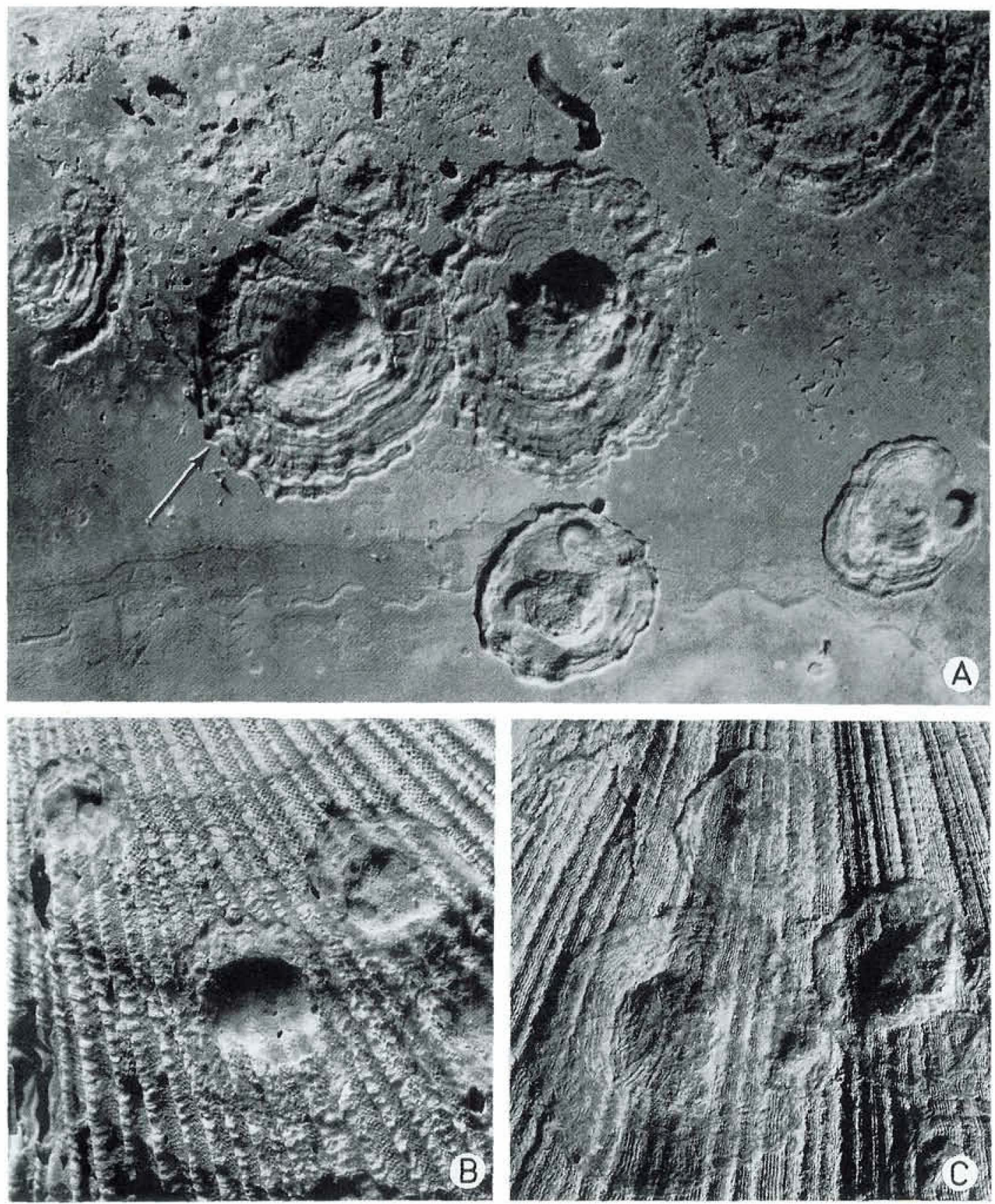

Figure 7. Centrichnus concentricus, nov. A: Holotype (arrowed) and paratypes on MGUH 19747, × 7. B: Four paratypes on MGUH 19748, $\times$ 5. C: Four paratypes on MGUH $19749, \times 5$. Below centre, two scars, a small and a large, overlap, indicating successive phases of colonization of the substrate; the earlier individual had fallen off before the later one occupied the site. 

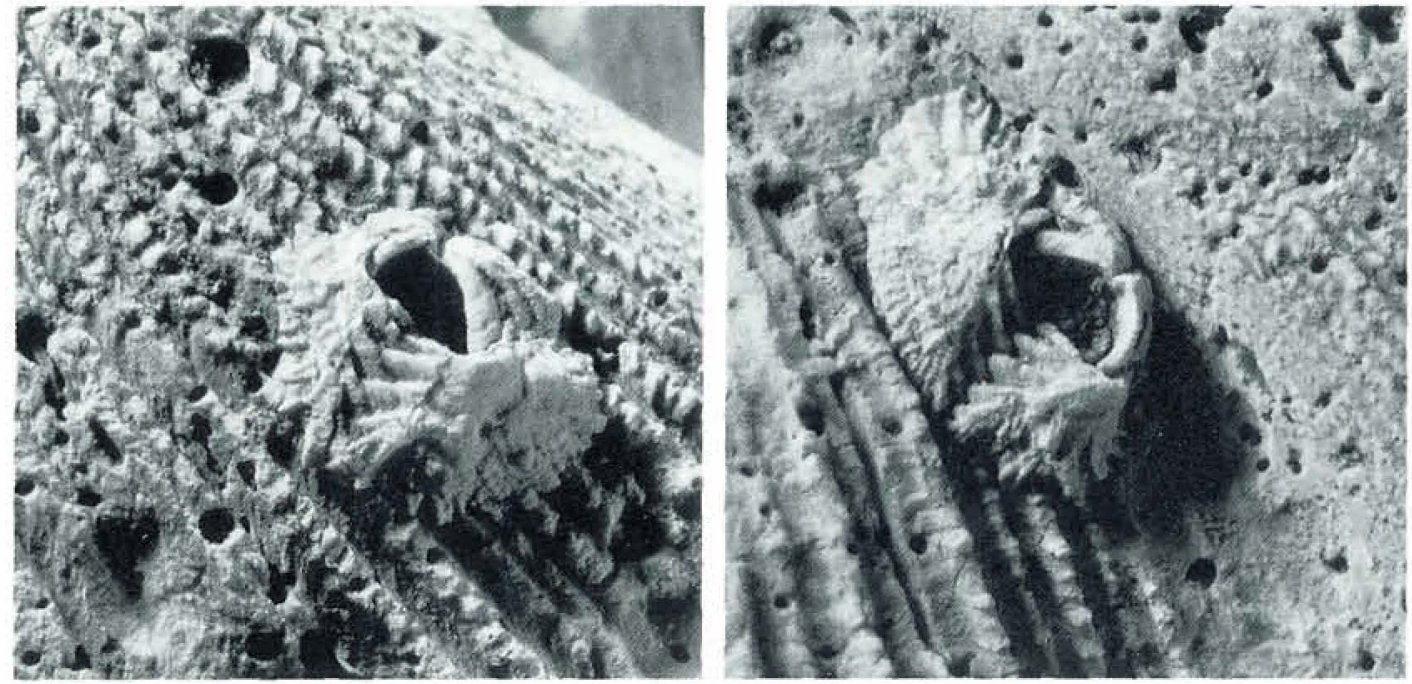

Figure 8. Two individuals of Verruca stroemia on a valve of Chlamys islandica from Kvam, northern Norway (Pleistocene). Morphology is variable in this species, being influenced by substrate topography; the elongate individual in $B$ is situated within the groove at the base of the ear of the pectinid. Corresponding variation in form is seen in the etching trace. MGUH $19750, \times 7$.

Holotype: one of several examples on the inner surface of a valve of Arctica islandica (fig. 7A). MGUH 19747.

Type locality: Palamós, Girona, Spain: Pleistocene, Würmian IV,

Paratypes: several individuals together with the holotype on MGUH 19747 (fig. 7A). Several individuals on MGUH 19748, the outer surface of a valve of Chlamys islandica from Kvam, northern Norway: Pleistocene (fig. 7B). Four individuals on MGUH 19749, a valve of Pseudamussium septemradiatum from Palamós: Pleistocene, Würmian IV.

Description: the crenulations of the oval to nearly circular outline are repeated on each of the concentric terraces or grooves that pattern the shelf. The form of the central depression cuts across this pattern, indicating that it has been enlarged at the expense of the shelf area. In some examples the shelf is virtually or completely smooth. Maximum size observed, $8.5 \mathrm{~mm}$; holotype $5 \mathrm{~mm}$ in diameter.

Interpretation: the intricate details of the structure perfectly agree with the etching traces produced by verrucid barnacles (Radwański 1977; Martinell \& Domènech 1982, pl. 2). Body fossils of these are commonly preserved in association with the trace fossils (fig. 8).

Range: Miocene to Recent.

Acknowledgements. We thank the following individuals for kindly supplying material: W. K. Christensen for the specimen illustrated in figure $6 \mathrm{~B}: \mathrm{N}$. Spjeldnas for the offshore Norwegian brachiopods; and E. Mayoral for comparative material of Renichnus arcuatus.

\section{Dansk sammendrag}

Smá, ovale og drábeformede, let-etsede ar i skaloverflader er ikke ualmindelige i marine miljøer. De findes pả både recent og fossilt materiale tilbage til Øvre Kridt. Disse to slags ar er beskrevet her, begge karakteriseret af concentriske vakstringe. Det ene er ovalt, med en central fordybning, og er forársaget af verrucide rurer; det bljwer kaldt Cenurichnos concentricus som sporfossil. Den anden form er dråbeformet i omrids, og er produceret af anomiide muslinger (sadelmuslinger): som sporfossil bliver den kaldt Centrichnus eccentricus. I begge tilfeide. er atsningen tolket som en made at forstarke fasthaftningen til underlaget.

\section{References}

Barnes, H. \& Topinka, J. A. 1969. Effect of the nature of the substratum on the force required to detach a common littoral alga. American Zoologisi 9: 753-758.

Brande, B. 1982. Epibiont analysis of the fossil interactions among a benthic infaunal bivalve, a barnacle and a drilling gastropod. Joumal of Paleontology 56: 1230-1234. 
Bromley, R. G. \& Surlyk, F. 1973. Borings produced by brachiopod pedicles, fossil and recent. Lethaia $6: 349-365$.

Bucquoy, E., Dolfus, P. \& Dautzenberg, G. 1887-1898. Les mollusques marins du Roussillon. II Pélécypodes. Paris: $884 \mathrm{p}$.

Darwin, C. 1854. A monograph of the sub-class Cirripedia. The Balanidae, the Verrucidae, etc. Ray Society: London.

Jackson, R. T. 1861. Phylogeny of Pelecypoda. Memoirs of the Boston Society for Natural History 4: 277-400.

Martinell, J. \& Domènech, R. 1982. Boring activity of epibionts in an Early Holocene molluscan fauna of Spanish Catalunya. Acta Geológica Hispánica 16: 145-149.

Mayoral, E. 1987. Acción bioerosiva de Mollusca (Gastropoda, Bivalvia) en el Plioceno inferior de la Cuenca del Bajo Guadalquivir. Revista Española de Paleontologia 2: 49-58.

Pilsbury, H. A. 1916. The sessile barnacles (Cirripedia) contained in the collections of the U.S. National Museum; including a monograph of the American species. United States National Museum Bulletin 93: 116 p.

Pujol, J. P., Bocquet, J. \& Tiffon, Y. 1970. Analyse biochimique du byssus calcifé d'Anomia ephippium L. (Mollusque bivalve). Calcified Tissue Research 5: 317-326.
Radwański, A. 1977. Present-day types of trace in the Neogene sequence; their problems of nomenclature and preservation. In Crimes, T. P. \& Harper, J. C. (eds) Trace fossils 2. Geological Journal Special Issues 9: 226-264.

Sassi, M. 1905. Zur Anatomie von Anomia ephippium. Arbeiten aus den zoologischen Instituten der Universität Wien und der zoologisches Station in Triest 15: 81-96.

Seed, R. 1980. Reproduction and growth in Anomia ephippium (L.) (Bivalvia: Anomiidae) in Strangford Lough, Northern Ireland. Journal of Conchology 30: 239-245.

Taylor, J. D., Kennedy, W. J. \& Hall, A. 1969. The shell structure and mineralogy of the Bivalvia. Introduction. Nuculacea - Trigonacea. Bulletin of the British Museum (Natural History) Zoology, Supplement 3: 125 pp.

Yonge, C. M. 1977. Form and evolution in the Anomiacea (Mollusca: Bivalvia) - Pododesmus, Anomia, Patro, Enigmonia, (Anomiidae): Placunanomia, Placuna (Placunidae fam. nov.). Philosophical Transactions of the Royal Society of London B 276: 453-523. 